\title{
ENTREPRENEURSHIP AND COVID-19
}

\author{
Kshitij Shinghal, Amit Saxena, Rajul Misra \\ Deptt. of Electronics \& Communication Engineering, \\ Deptt. of Electrical Engineering, \\ Moradabad Institute of Technology, \\ Moradabad, U.P., 244001, India
}

\begin{abstract}
We all know that world is facing a challenge in the form of disease coronavirus. The role of innovation creativity and entrepreneur mindset among young students with science and technology background is very important. The idea is to develop right idea at right time and convert it into product so as to help the nation and society to fight against pandemic disease. Young students can be easily encouraged and motivated to give new creative and innovative ideas which can be implemented and converted in to product form. It is the role of young entrepreneurs to develop technology and produce it to support economy of nation and support the society.
\end{abstract}

\section{KEYWORDS: Entrepreneurship, covid-19, innovations}

\section{INTRODUCTION}

We all are aware that the whole world is under the threat of pandemic disease covid-19. There exists no known medicine to cure novel Corona virus and there is no vaccine for covid-19 also known as SAARS virus-2. The only solution to fight these disease is prevention by wearing masks, social distancing and lock downs. The virus is so infectious and fast spreading that once it reaches level 3 and community is started it is very difficult to control its spread.

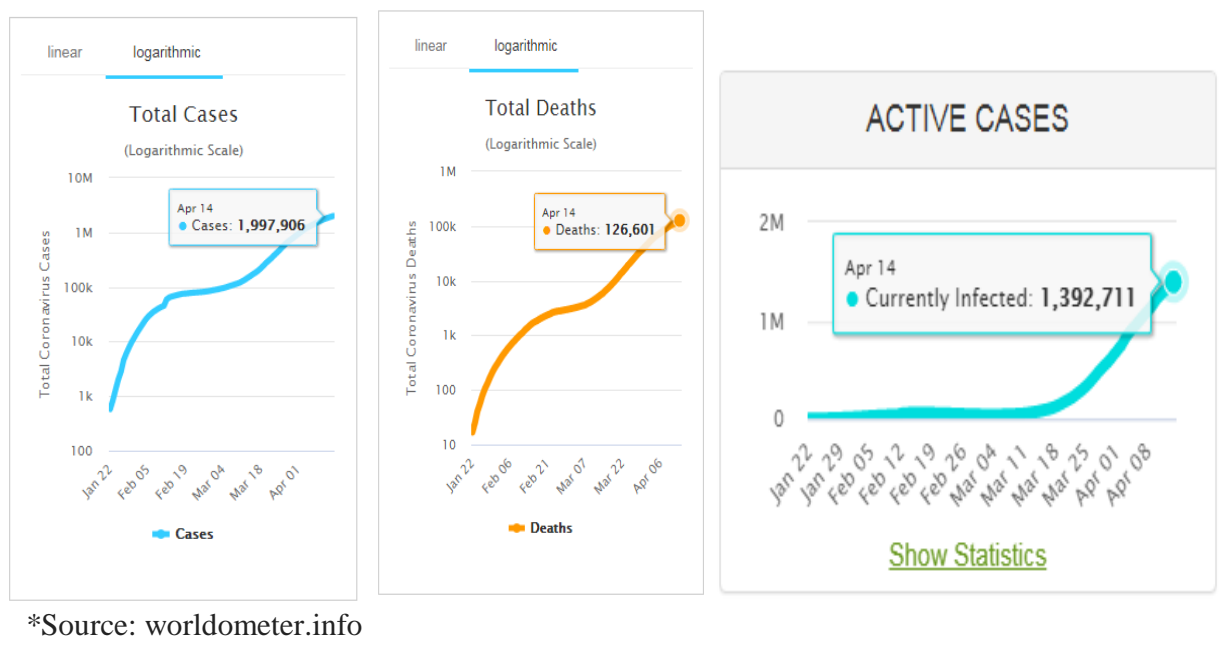

Figure 1: Graph of total cases, active cases \& death cases all over the world due to Covid 19 [1]

Most of the developed countries of world are facing the serious outbreak of the disease [1]. 
International Journal of Scientific Research and Management Studies (IJSRMS)

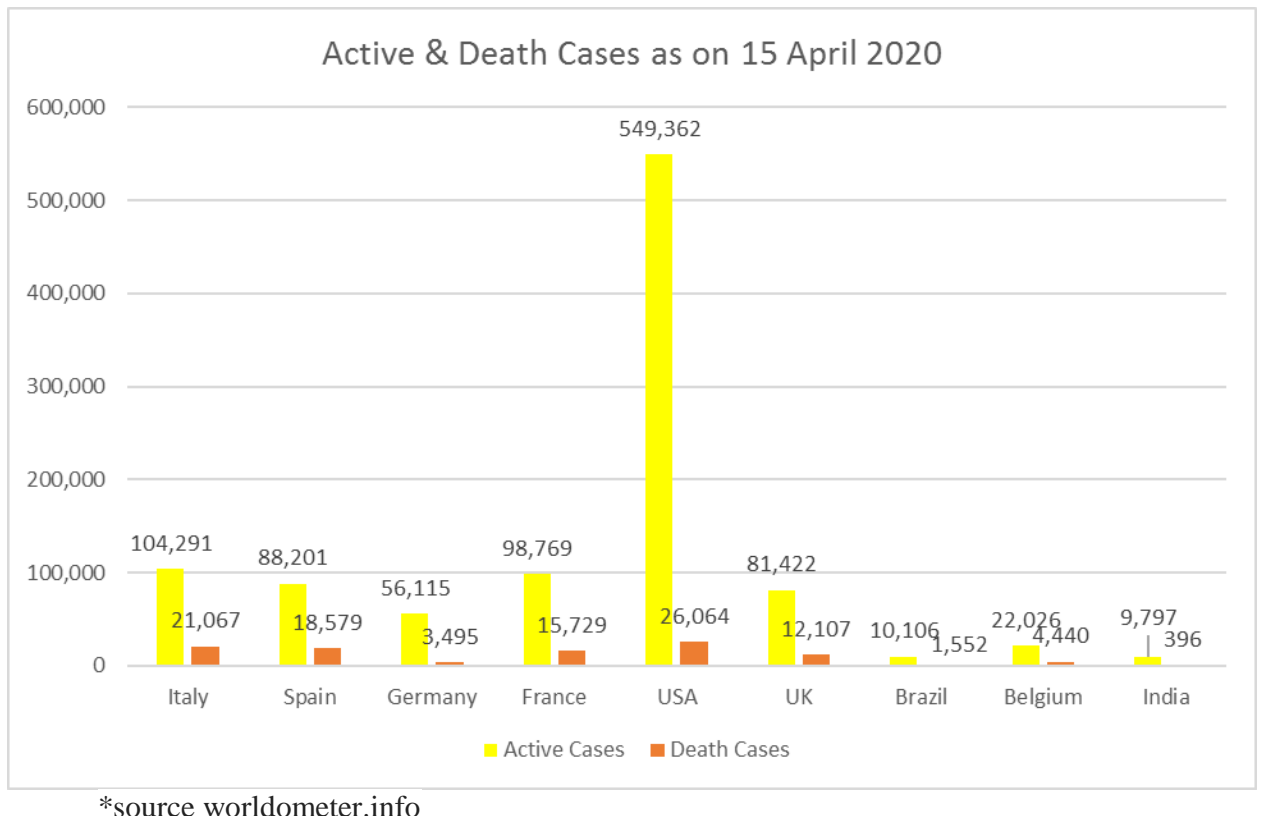

*source worldometer.info

Figure 2: Active \& death cases in major countries [1]

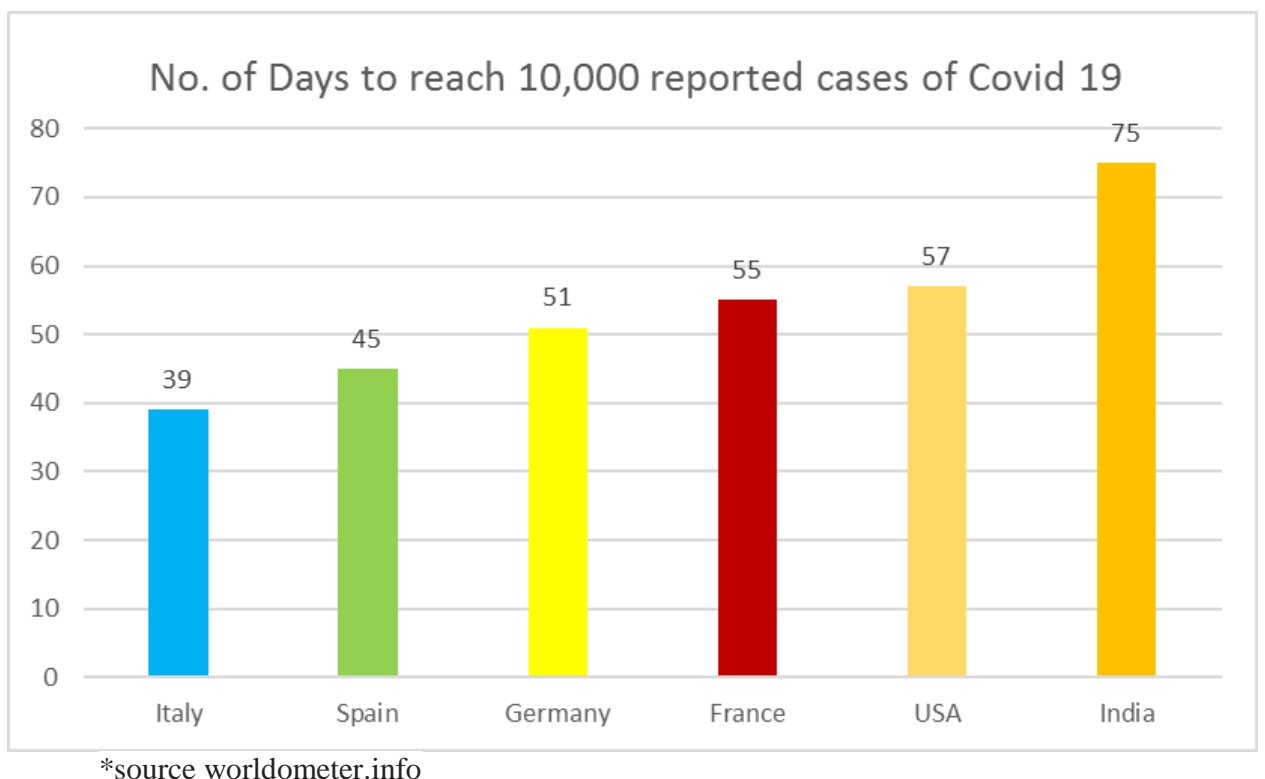

Figure 3: Growth of Covid 19 from 0 to 10,000 in various countries [1]

Most of the countries are facing challenges in supplying masks, medicines, medical equipments, ventilators, and other technology based creative and innovative solutions. Here comes an important role that can be played by young science and technology background students. They can give the innovative, creative, technology based solutions to fight pandemic disease. The key is not only to give the right solution at right time but also to timely validate it, build a prototype and start producing it [2, 3]. Time is the key factor, and again the creative idea alone is not sufficient an action plan to implement the idea is also necessary. Here comes the next level after innovation i.e. startup or role of an entrepreneur. However one should possess the key entrepreneurial skills so that right decision at right time should be taken to benefit the society [4]. 


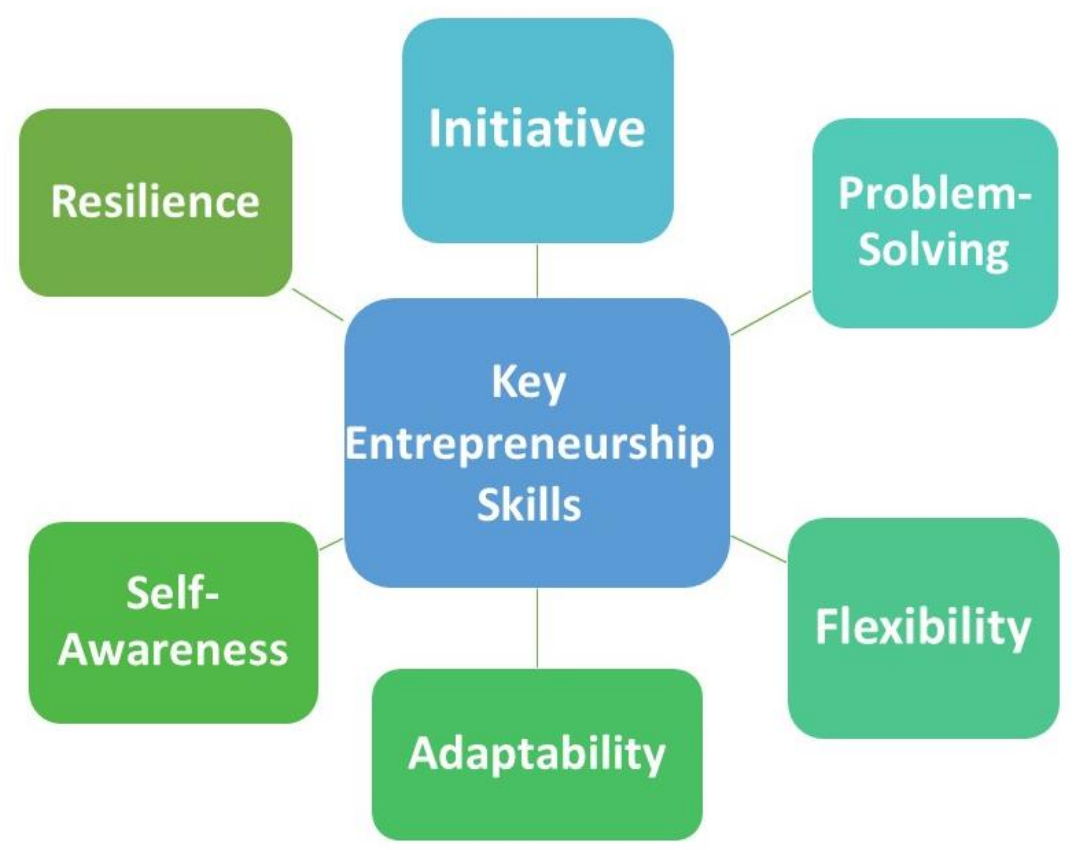

Figure 4: Key entrepreneurial skills (Shinghal, K., 2018)

Academicians, teaching community and young students at technical and engineering institute are still struggling to make employable engineers or to become employable engineers at top notch companies. Still lacking at producing employment generating, innovations implementing, economy sustaining and contributing to development of nation by following startup, entrepreneurship and business and other medical equipments development ideology [5-7].

Rest of the paper is divided into different sections for the ease of understanding. Section II depicts the proposed methodology and section III provides the results and discussion. At the end, conclusion of the work has been given in section IV.

\section{PROPOSED MeTHODOLOGY}

In today's critical condition with covid-19 spreading all over the world even the most advanced countries all over the world are facing the shortage of ventilators, masks and other medical equipments. At least now in this Critical condition scientists, researchers and students with science and technology background should realize the importance of entrepreneurship and proving themselves as useful citizen of country. Science, Technology innovation, creativity research is useless without proper implementation until it is converted in to a product useful to the society.

For example, if engineers can develop various apps, information channels, for creating awareness about pandemic in current scenario. Electronics and computer engineers can develop gadgets to detect and generate alert signals for Corona victims, mechanical assembly lines can be customized to mass produce medical equipments, masks, ventilators and other medical equipments. Pharmacists allopathic and ayurvedic physicians may develop immunity boosters and so on. But the requirement is awareness to become manufacturers, producers, entrepreneurs rather than meek observers. This is the high time a signal for all technocrats, educators, innovators, researchers to start doing real work, to bring out research from papers to real products and produce them. It is the time to develop adaptable mindset, to recognize the importance of having customizable production capabilities. The time to leave stereotype conventional thinking do something worthy for nation, society and whole world. In airplanes they announce during emergency oxygen masks will drop. But before helping others first affix you mask properly. Similarly if you have adaptable, customizable production capabilities to implement creative ideas you can first serve your community, then, region, then nation, then society and then whole world. But the challenge is to develop entrepreneurial mindset, courage to procure creative ideas, implement them and produce them. 


\section{RESULT AND DISCUSSION}

From the proposed methodology it is evident it is the high time to promote scientists, researchers, students, scholars with science and technology background to start implementing ideas and manufacturing it. Because an innovative idea without implementation is like a body without soul. If an idea cannot be implemented and put in action to serve the society than it is of no use. Further we need to develop assembly lines which can be easily customized to mass produce any other product only by making simple tweaks or rearrangement of machinery. Finally entrepreneur should not limit their scope to making particular product or consider themselves as working for profit only, but they should be ready to face any challenges an provide solutions to the problem that society is facing at any particular time.

\section{CONCLUSION}

To Sum up, three basic idea emerge from this paper, first and the most important one is entrepreneur and Entrepreneurship as a concept must not remain confined to economic sphere only but should be easily adaptable and convertible as per the situation. That is expanding its scope and boundaries to other avenues of life. Second idea is innovations without implementation are just imaginations, pipe dreams of no use to society. So the aim of educators, researchers, creative thinkers should be to promote development of entrepreneurial mindset. Third and final conclusion is that entrepreneurs should be ready to take challenges. Though they might be working in one avenue of life they must be ready to adopt to new situation, give solutions as per the requirements and customize their production capabilities accordingly.

\section{ACKNOWLEDGEMENT}

We owe our sincere feelings of gratitude to MIT Group of Institutions, Moradabad. We are also thankful to Prof. Rohit Garg, Director MIT \& Prof. R. Yadav, former Director General MIT their support, guidance and suggestions, which helped us a lot to write the paper. We also wish to acknowledge the motivation and support provided by Entrepreneurship Development Institute of India (EDII), Ahmedabad and National Institute for Entrepreneurship \& Small Business Development (NIESBUD), Noida.

\section{REFERENCES}

[1]. Covid-19 Coronavirus Pandemic, https://www.worldometers.info/coronavirus/ 15 April 2020.

[2]. Shinghal, K., Saxena, A. (2017) 'Developing Entrepreneurial Mindset in Engineers', Int. J. of Scientific Research and Management Studies (IJSRMS), Volume 4 Issue 2, pp. 56-59, Sept. 2017.

[3]. Shinghal, K., Saxena, A. (2018) 'Effective Entrepreneurship Education through Teaching Case', Int. J. of Engineering Sciences \& Emerging Technologies, Volume 10, Issue 3, pp: 82-84, Mar. 2018.

[4]. Shinghal, K., Saxena, A. (2018) 'Importance of Nurturing Entrepreneurship Skills in Students', Int. J. of Recent Trends in Electrical \& Electronics Engg. (IJRTE), Volume 7, Issue 1, pg 13-16, Aug., 2018.

[5]. Shinghal, K., Saxena, A. (2019) 'Entrepreneurship Opportunities Innovations and Ecosystem', Int. J. of Advances in Engineering \& Technology (IJAET), Volume 12 Issue 6, pp. 99-103, December 2019.

[6]. Shinghal, K., Saxena, A. (2020) 'Analysis of Entrepreneurial Mindset in Engineering Students', Int. J. of Advances in Engineering \& Technology (IJAET), Volume 13 Issue 1, pp. 13-23, February 2020.

[7]. L. S. Zvyagin, (2015) 'The new economic reality and risk in development of innovative entrepreneurship', 2015 IV Forum Strategic Partnership of Universities and Enterprises of Hi-Tech Branches (Science. Education. Innovations), St. Petersburg, 2015, pp. 39-41. 